\title{
Biodiesel production and nutrient removal by microalgae cultured on poultry waste
}

\author{
Effat Fahmy Shabana, Fatma Elzahraa Taofik \\ and Hanaa Sayed Shalaby *
}

Botany and Microbiology Department, Faculty of Science, Cairo

\begin{abstract}
:
Microalgae are a potential feedstock for a vast renewable products and different applications in biotechnology. This investigation of using poultry waste extracts for growing Anabaena, Chlorella and mixed culture of both showed that $5 \mathrm{~g} / \mathrm{L}$ poultry waste extract was the most probable concentration for enhancing growth and lipid production. Percentage increase in lipid content over control (BBM) was (94.2, 56.4 and $28.8 \%$ ), biomass productivity was $(31.61,51.86$ and $42.04 \mathrm{mg} / \mathrm{L} /$ day) and lipid productivity was (4.59, 10.53 and $6.94 \mathrm{mg} / \mathrm{L} /$ day) for Anabaena, Chlorella and mixed culture respectively. The role of microalgae in bioremediation of poultry waste was effective, maximum reduction percentage of $\mathrm{NH}_{3}$ was $(84.07 \%)$ whereas it was (80.41\%) for phosphorus. Microwave pretreatment of harvested cells increased the lipid content to $17.6 \%$ in Anabaena, 31\% in Chlorella and 23\% for mixture. Lipid extraction, esterification, GC-Ms analysis for fatty acid profile, showed that saturated fatty acids in Chlorella and algal mixture were higher than their corresponding controls. Cetane number of the produced biodiesel was ranged from (53.7 to 56.4) while iodine value was ranged from (63.5 to 88.4). This study revealed that poultry waste extract can be used as a promising ecofriendly microalgae medium for high production of biomass and lipid which in turn produce high quality biodiesel meet the international standards biodiesel.
\end{abstract}

Keywords: Biodiesel, Bioremediation, Poultry, Pretreatment, Microalgae, waste.

\section{Introduction}

The worldwide interest in developing of renewable sustainable, clean alternative energy sources to meet current and future demands has been vigorously increased after the depletion of oil reserves, the resulting increase in fossil fuel prices, the international awareness of the environmental impact of greenhouse gas emissions (Posten and Schaub 2009 ; Rawat et al., 2011 and 
Bacenetti et al., 2015). Energy consumption grew in 2010 by $5.6 \%$; it was the largest percentage of increase in almost last years (Jones \& Mayfield, 2012) and (Alam et al., 2012). So, the world is actually facing two critical problems and challenges, energy depletion and also environmental pollution. The production of clean energy accompanied by the concerns of environmental risks, national security had raised the attention towards fuel (Gupta and Tuohy, 2013). So there is a persistent need for developing new ecofriendly sustainable energy sources for supporting of modern society. Wastes like sewage, industrial wastes and poultry and animal wastes have now become one of the major sources of pollution. In addition to organic carbon, wastes also contain large amount of organic and inorganic nutrients like nitrogen, phosphate, nitrate, ammonia, soluble and insoluble salts and protein, etc. (Cho et al., 2013) which considered the principal factor for eutrophication and a lot of human and animal diseases in aquatic bodies. Recently, microalgae have emerged as a source that can play the dual role of bioremediation of wastes and generation of biomass for biodiesel production (Kligerman and Bouwer, 2015). The poultry industry produces large amounts of waste that include solid waste and wastewater, one of the solid wastes is excreta (Moreki and Keaikitse 2013). Poultry waste has been a traditional organic alternative source of fertilizers which is economically beneficial to use rather than chemical fertilizer, and this also reduces the environmental pollution of manure caused by the inappropriate disposal from which much needed nutrients can be retrieved and reutilized (Jacob-Lopes et al., 2008 \& 2009). Bhatnagar et al., (2011) reported that poultry litter extract as growth medium for some microalgal species (Chlamydomonas globosa, Chlorella minutissima and Scenedesmus bijuga ) recorded up to $180 \%$ more biomass growth compared to standard growth medium BG11. Microalgae like (Chlorella, Dunaliella and Spirulina) primarily grown photoautotrophically at the same time it could be able to grow heterotrophically by converting organic and inorganic waste substances to biomass and subsequently lipid for biodiesel production. Microalgae have been used as a successful biological treatment agent due to its central role in carbon cycle as a photosynthetic organisms and pollution reduction by removing major pollutants such as $\mathrm{P}, \mathrm{N}$, and $\mathrm{S}$ (Bhatnagar et al., 2010). These nutrients in wastes, make it a cheap and sustainable alternative media for growing microalgae for biodiesel production. Biodiesel (monoalkyl esters) is one of such alternative biofuel, which can be obtained by the transesterification of oil with alcohols. It 
has been well-reported that biodiesel can be obtained from algal oil as a diesel fuel substitute (Lang et al., 2002; Spolaore et al., 2006). This double benefits of using microalgae in waste treatment and biodiesel production received growing excessive attention over the years because of excessive biomass generation at cheaper cost without further addition of chemical nutrients (Kothari, et al., 2012). Thus, the present study aims to use poultry waste as an alternative nutrient source, generate microalgal biomass with low cost to produce biodiesel, at the same time reducing the pollution load.

\section{Materials and Methods}

\section{Organisms:}

Anabaena oryzae Fritsch and Chlorella vulgaris Beijerinck were obtained from the Culture Collection of Botany and Microbiology Department, Faculty of Science, Cairo University, Egypt.

\section{Methods of experimentation and growth conditions:}

Poultry waste was collected from an egg lying chickens poultry farm in Giza city. Sun dried poultry solid waste was ground into a fine powder. After preliminary test selected poultry waste extract concentrations were prepared by suspending $1,3,5,7$ and $9 \mathrm{~g}$ of the poultry dry waste in one liter of tap water, heated to $50{ }^{\circ} \mathrm{C}$ for 20 minutes and then filtered (Agwa et al., 2012 with some modifications), three conical flasks for each concentration and control (cultivated in BBM) were inoculated with $20 \mathrm{ml}$ of exponentially grown microalgae A.oryzae, C. vulgaris and a mixture of both (freshly prepared), they were incubated for 14 days under optimum growth conditions $\left(40.5 \mu \mathrm{E} \mathrm{m}^{-2} \mathrm{~S}^{-1} \& 25 \pm\right.$ $2^{\circ} \mathrm{C}$ ) till reaching the stationary phase (from growth curve experiment).Microalgal cells were harvested, by centrifugation, chlorophyll (a) content and dry weight, were estimated according to (APHA, 1998). Total lipids content were extracted by Soxhlet Extractor according to (Sadasivam and Manikam, 1996), using chloroform / methanol 2:1 v/v (Afify et al., 2010). Physicochemical characteristics of $5 \mathrm{~g} / \mathrm{L}$ poultry waste extract were, analyzed 
before and after microalgal cultivation for $(5 \mathrm{~g} / \mathrm{L})$ concentration which gives the highest total lipids, analyzed parameters were biological oxygen demand (BOD), chemical oxygen demand (COD), total dissolved solids (TDS), total suspended solids (TSS), Phosphorus(P), ammonia $\left(\mathrm{NH}_{3}\right)$, Nitrate $\left(\mathrm{NO}_{3}\right)$ and total nitrogen (TN) were estimated according to (APHA, 2005).Biomass productivity was calculated according to Abomohra et al., (2013).The lipid productivity was calculated according to (Converti et al., 2009).

Transesterfication for fatty acid analysis was carried out by mixing the produced oil with a mixture of catalyst $(0.25 \mathrm{~g} \mathrm{NaOH})$ and $24 \mathrm{ml}$ methanol with stirring properly for $20 \mathrm{~min}$, the mixture was kept for $3 \mathrm{hrs}$. in shaker at $300 \mathrm{rpm}$ (Afify et al., 2010). Samples were analyzed for fatty acid profiles using gas chromatography - mass spectrometry (GC/Ms) in the Central Lab of Residue Analysis of Pesticides and Heavy Metals. For biodiesel production microalgae were grown on $(5 \mathrm{~g} / \mathrm{L})$ poultry waste extract for 14 days, microalgal pellets were harvested and the experiment was repeated several times to obtain the required biomasses. Wet microalgal cells were pretreated in a microwave oven at about $100{ }^{\circ} \mathrm{C}$ and $2450 \mathrm{MHz}$ for five minutes as the best method for cell disruption (Lee et al, 2010). The produced biodiesel samples were analyzed at Egyptian Petroleum Research Institute according to (ASTM).

\section{Statistical analysis:}

It was carried out using SPSS program. Results were presented as mean \pm standard deviation (SD). Multiple comparisons of means were made with Duncan's multiple range tests at 95\% (Dytham, 1999).

\section{Results and Discussion}

Primarily analysis of poultry waste extract indicated that the proximate composition of the waste extract contain essential micronutrients required for the growth of Anabaena and Chlorella.

Results recorded in Table (1) shows that increasing poultry waste extract concentration growth and lipid production of Anabaena, Chlorella and their 
mixture significantly and gradually increased chl. a, dry weight and lipid content, where it reached its maximum value at $5 \mathrm{~g} / \mathrm{L}$ exceeding control culture by $(12.8$, 18.2, and 27.4\%), (35.1, 32.9 and 17.7\%) and (94.2, 56.4 and 28.8\%), respectively. This is in agreement with Lee and Wilson (2015), who reported that cells of microalgae offers treat of the wastewater by biological pathway, allowing to handle a range of substrates at various concentrations and that reported by Markou et al., (2015), who founded that poultry litter ash is very rich in nutrient elements for the production of microalgae biomass and could be up taken by these microorganisms. In a previous study, Agwa and Abu (2014) reported that it is seemed to be there was no lag phase with the poultry waste extract but the growth response of synthetic media was slow with a lag phase of about three days required for adaptation of media with microalgae. Maximum lipid content and percentage ( $147.45 \mathrm{mg} / \mathrm{l}$ and $20.31 \%$ ) was obtained by Chlorella culture cultivated on poultry waste extract, the present result is in agreement with (Sivaramakrishnan and Incharoensakdi, 2017), who reported that the total lipid contents of the microalgae can be improved by growth condition under various stresses including required nutrients, to decrease the production costs

The maximum biomass productivity was at $5 \mathrm{~g} / \mathrm{L}$ poultry waste extract 31.61, 51.86 and $42.04 \mathrm{mg} / \mathrm{L} /$ day for $A$. oryzae, $C$. vulgaris and their mixed culture respectively. In a similar trend maximum lipid productivity was 4.59, 10.53 and $6.94 \mathrm{mg} / \mathrm{L} /$ day for Anabaena, Chlorella and their mixture (Fig.1). In this aspect Ali et al ., (2017) reported that algae can be accumulate from 1 to $84 \%$ of lipids, which greatly depends on suitable growth conditions, nutrient level and the type of organism . Algae also can be utilized for wastewater treatment and their biomass can be utilized as a feedstock to produce biofuels. Agricultural wastewater with different animal wastes (poultry and cow) are rich with nutrients. So it can be utilized as growth medium for microalgae cultivation (Manzoor et al., 2015). Eladel et al., (2019), reported that there was a significant increase in lipid productivity of Chlorella sorokiniana cultivated on municipal wastewater over that of Bolds basal medium (BBM) and attributed that increase to the availability of organic compounds in wastewater. 
Table 1: Effect of different concentrations of poultry waste extract on growth and lipid production of microalgae after 14 days growth.

\begin{tabular}{|c|c|c|c|c|c|c|c|c|c|c|c|c|}
\hline \multirow{2}{*}{$\begin{array}{l}\text { Conc. } \\
(\mathrm{g} / \mathrm{L})\end{array}$} & \multicolumn{4}{|c|}{$\begin{array}{l}\text { Anabaena oryzae } \\
\text { ( parameters } \mathrm{mg} / \mathrm{L})\end{array}$} & \multicolumn{4}{|c|}{$\begin{array}{l}\text { Chlorella vulgaris } \\
\text { ( parameters mg/L) }\end{array}$} & \multicolumn{4}{|c|}{$\begin{array}{c}\text { Mixture of } A . \text { oryzae and } C \text {. vulgaris } \\
\text { ( parameters } \mathrm{mg} / \mathrm{L})\end{array}$} \\
\hline & $\begin{array}{l}\text { Chl. } \\
\text { (a) }\end{array}$ & Dry weight & $\begin{array}{l}\text { Lipid } \\
\text { content }\end{array}$ & $\begin{array}{c}\text { Lipid } \\
\% \\
(w / w)\end{array}$ & $\begin{array}{l}\text { Chl. } \\
\text { (a) }\end{array}$ & Dry weight & $\begin{array}{l}\text { Lipid } \\
\text { content }\end{array}$ & $\begin{array}{c}\text { Lipid } \\
\% \\
(w / w)\end{array}$ & $\begin{array}{l}\text { Chl. } \\
\text { (a) }\end{array}$ & $\begin{array}{c}\text { Dry } \\
\text { weight }\end{array}$ & $\begin{array}{c}\text { Lipid } \\
\text { content }\end{array}$ & $\begin{array}{c}\text { Lipid } \\
\% \\
(w / w)\end{array}$ \\
\hline $\begin{array}{l}\text { Control } \\
(\mathbf{0 . 0})\end{array}$ & $\begin{array}{c}6.55 \pm \\
0.21^{\mathrm{d}}\end{array}$ & $327.7 \pm 8.10^{d}$ & $\begin{array}{c}33.07 \pm \\
0.80^{c}\end{array}$ & $\begin{array}{c}10.09 \pm \\
0.04^{\mathrm{a}}\end{array}$ & $\begin{array}{c}8.68 \pm \\
0.17^{d}\end{array}$ & $546.2 \pm 15.38^{d}$ & $\begin{array}{c}94.31 \pm \\
2.45^{d}\end{array}$ & $\begin{array}{c}17.28 \pm \\
0.92^{\mathrm{a}}\end{array}$ & $\begin{array}{c}6.57 \\
\pm \\
0.15^{d}\end{array}$ & $\begin{array}{l}499.9 \pm \\
11.39^{d}\end{array}$ & $\begin{array}{c}75.40 \pm \\
1.80^{d}\end{array}$ & $\begin{array}{r}15.08 \\
\pm 0.02^{\mathrm{a}}\end{array}$ \\
\hline 1 & $\begin{array}{c}1.76 \pm \\
0.18^{\mathrm{a}}\end{array}$ & $85.36 \pm 9.12^{a}$ & $\begin{array}{c}13.03 \pm \\
0.58^{\mathrm{a}}\end{array}$ & $\begin{array}{c}15.34 \pm \\
1.20^{b}\end{array}$ & $\begin{array}{c}2.47 \pm \\
0.10^{\mathrm{a}}\end{array}$ & $195.1 \pm 7.83^{\mathrm{a}}$ & $\begin{array}{c}39.83 \pm \\
1.78^{\mathrm{a}}\end{array}$ & $\begin{array}{c}20.43 \pm \\
1.18^{b}\end{array}$ & $\begin{array}{c}2.07 \\
\pm \\
0.21^{\mathrm{a}}\end{array}$ & $\begin{array}{r}167.23 \\
\pm 8.06^{a}\end{array}$ & $\begin{array}{c}27.85 \pm \\
1.22^{\mathrm{a}}\end{array}$ & $\begin{array}{c}16.66 \pm \\
0.09 b^{c}\end{array}$ \\
\hline 3 & $\begin{array}{c}3.12 \pm \\
0.30^{b}\end{array}$ & $\begin{array}{c}143.32 \pm \\
10.62^{b}\end{array}$ & $\begin{array}{c}20.74 \pm \\
1.28^{b}\end{array}$ & $\begin{array}{c}14.48 \pm \\
0.19^{b}\end{array}$ & $\begin{array}{r}3.79 \\
\pm 0.26^{b}\end{array}$ & $304.9 \pm 11.11^{b}$ & $\begin{array}{c}61.90 \pm \\
2.69^{b}\end{array}$ & $\begin{array}{c}20.31 \pm \\
0.93^{b}\end{array}$ & $\begin{array}{c}3.21 \pm \\
0.44^{b}\end{array}$ & $\begin{array}{c}229.83 \\
\pm \\
14.19^{b}\end{array}$ & $\begin{array}{c}39.08 \pm \\
2.09^{b}\end{array}$ & $\begin{array}{c}17.01 \pm \\
0.22^{c}\end{array}$ \\
\hline 5 & $\begin{array}{c}7.39 \pm \\
0.53^{\mathrm{e}}\end{array}$ & $442.57 \pm 11.54^{f}$ & $\begin{array}{c}64.22 \pm \\
1.21^{\mathrm{f}}\end{array}$ & $\begin{array}{c}14.51 \pm \\
0.11^{b}\end{array}$ & $\begin{array}{r}10.26 \\
\pm 0.32^{\mathrm{e}}\end{array}$ & $726.00 \pm 16.03^{e}$ & $\begin{array}{l}147.45 \\
\pm 3.44^{\mathrm{e}}\end{array}$ & $\begin{array}{c}20.31 \pm \\
0.03^{b}\end{array}$ & $\begin{array}{c}8.37 \pm \\
0.40^{\mathrm{e}}\end{array}$ & $\begin{array}{c}588.53 \\
\pm 17.35^{f}\end{array}$ & $\begin{array}{c}97.14 \pm \\
2.27^{f}\end{array}$ & $\begin{array}{c}16.51 \pm \\
0.50^{b}\end{array}$ \\
\hline 7 & $\begin{array}{c}6.48 \pm \\
0.20^{d}\end{array}$ & $\begin{array}{c}421.07 \pm \\
6.64^{\mathrm{e}}\end{array}$ & $\begin{array}{c}60.71 \pm \\
0.83^{\mathrm{e}}\end{array}$ & $\begin{array}{c}14.42 \pm \\
0.13^{b}\end{array}$ & $\begin{array}{c}9.04 \\
\pm \\
0.18^{d}\end{array}$ & $709.06 \pm 18.96^{\mathrm{e}}$ & $\begin{array}{r}143.65 \\
\pm 4.66^{\mathrm{e}}\end{array}$ & $\begin{array}{c}20.26 \pm \\
0.12^{b}\end{array}$ & $\begin{array}{c}7.05 \pm \\
0.12^{d}\end{array}$ & $\begin{array}{c}541.23 \\
\pm 12.76^{\mathrm{e}}\end{array}$ & $\begin{array}{c}90.17 \pm \\
2.06^{\mathrm{e}}\end{array}$ & $\begin{array}{c}16.66 \pm \\
0.16 b^{c}\end{array}$ \\
\hline 9 & $\begin{array}{c}5.24 \pm \\
0.14^{\mathrm{c}}\end{array}$ & $\begin{array}{c}257.26 \\
\pm 17.64^{c}\end{array}$ & $\begin{array}{c}37.23 \pm \\
2.35^{d}\end{array}$ & $\begin{array}{c}14.47 \pm \\
\mathbf{0 . 0 8}^{\mathrm{b}}\end{array}$ & $\begin{array}{c}7.07 \pm \\
0.29^{\mathrm{c}}\end{array}$ & $409.00 \pm 21.10^{c}$ & $\begin{array}{c}83.79 \pm \\
5.20^{c}\end{array}$ & $\begin{array}{c}20.48 \pm \\
0.21^{b}\end{array}$ & $\begin{array}{c}5.89 \pm \\
0.18^{\mathrm{c}}\end{array}$ & $\begin{array}{c}286.12 \\
\pm 15.66^{c}\end{array}$ & $\begin{array}{c}48.43 \pm \\
2.43^{c}\end{array}$ & $\begin{array}{c}16.93 \pm \\
0.18 b^{c}\end{array}$ \\
\hline
\end{tabular}

*Means marked with the same superscript letters are not-significant $(\mathrm{P}>0.05)$, whereas others with different superscript letters are significant $(\mathrm{P}<0.05)$. Data are average of three replicates; each value represents the mean $\pm \mathrm{SD}$. (Control): cultivated on BBM. 


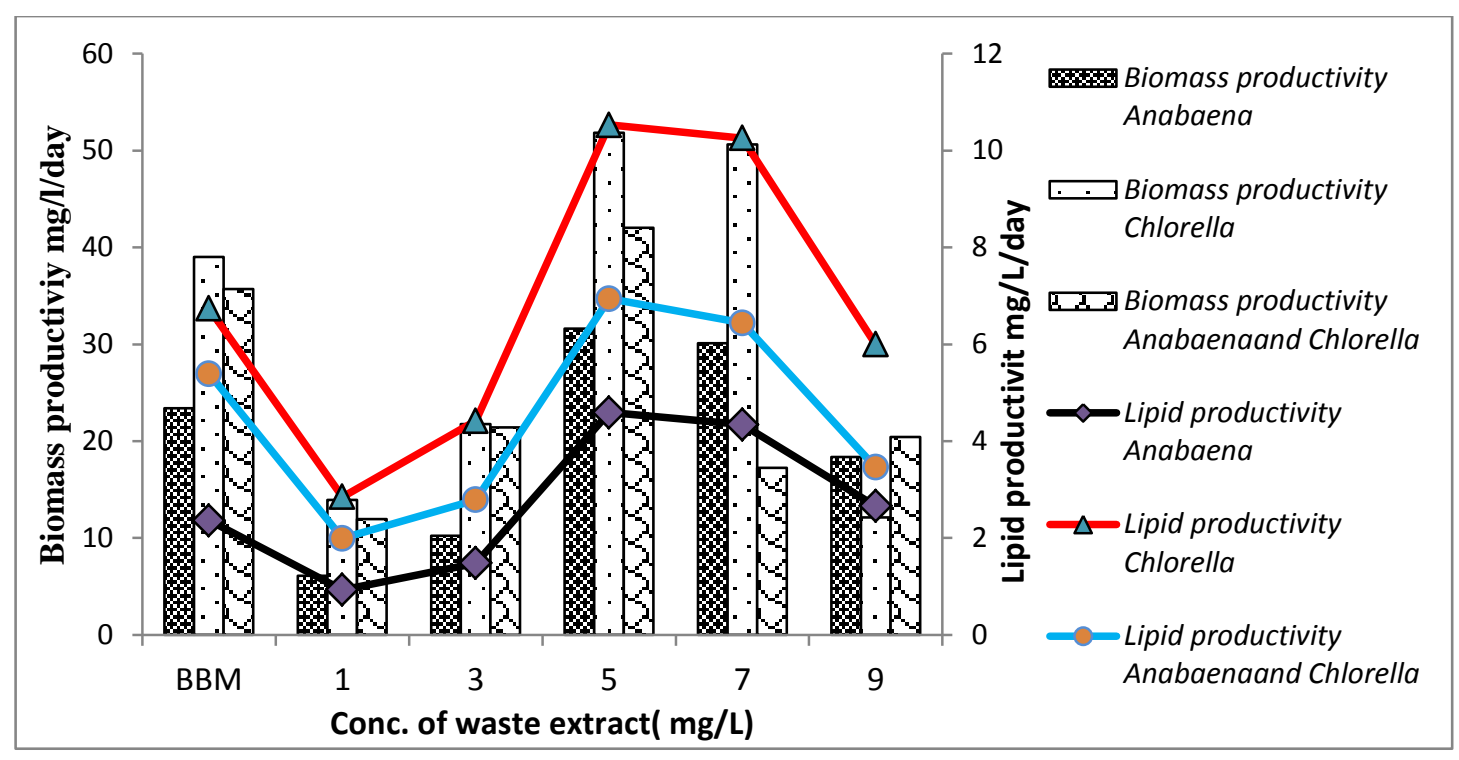

Fig.1: Effect of different concentrations of poultry waste extract on biomass productivity and lipid productivity of Anabaena oryzae, Chlorella vulgaris and mixed culture of them after 14 days growth.

There was a noticeable decrease in concentration of TSS and TDS in $5 \mathrm{~g} / \mathrm{L}$ poultry waste extract after microalgal cultivation, for 14 days. The reduction percentage with Anabaena was $(67.78 \& 81.53 \%)$, whereas it was $(70.9 \& 82.69$ $\%)$ and $(69.74 \& 82.45 \%)$ in Chlorella and mixed culture. The maximum reduction efficiency of BOD $(76.11 \%)$ and COD $(75.6 \%)$ recorded by Chlorella at the end of incubation period.TN and $\mathrm{NH}_{3}$ content were highly decreased by Anabaena, Chlorella and their mixture, the highest removal efficiency of TN (84\%) was detected by Chlorella while with $\mathrm{NH}_{3}$ it was detected by mixed culture $(84.07 \%)$. Nitrate content was obviously decreased after incubation and reduction percentage reached $100 \%$ with mixed culture while the highest removal efficiency of phosphorus (80.41\%) was detected with Anabaena (Table 2 ).These agreed with Eladel et al., (2019) and Nadiah et al ., (2018) who said that growing 
of microalgae in wastewater remove nutrients and produce biomass can be converted to biodiesel

Table 2: Analysis of poultry waste extract $(5 \mathrm{~g} / \mathrm{L})$ before and after microalgal cultivation for 14 days

\begin{tabular}{|c|c|c|c|c|c|c|c|}
\hline \multirow{2}{*}{$\begin{array}{c}\text { Parameter } \\
\text { (mg/L) }\end{array}$} & \multirow{2}{*}{$\begin{array}{c}\text { Initial } \\
\text { mg/L } \\
\text { (Before } \\
\text { inoculation) }\end{array}$} & \multicolumn{2}{|c|}{ Anabaena oryzae } & \multicolumn{2}{|c|}{ Chlorella vulgaris } & \multicolumn{2}{|c|}{ Mixed culture } \\
\hline & & Final (mg/L) & $\begin{array}{l}\quad \% \text { of } \\
\text { reduction }\end{array}$ & Final ( mg/L) & $\begin{array}{l}\quad \% \text { of } \\
\text { reduction }\end{array}$ & $\begin{array}{l}\text { Final } \\
\text { (mg/L) }\end{array}$ & $\begin{array}{l}\quad \% \text { of } \\
\text { reduction }\end{array}$ \\
\hline TSS & $49.93 \pm 1.80$ & $16.10 \pm 1.15$ & $67.78 \pm 1.25$ & $14.53 \pm 0.65$ & $70.90 \pm 0.26$ & $15.07 \pm 1.45$ & $69.74 \pm 3.85$ \\
\hline TDS & $501.67 \pm 8.50$ & $92.63 \pm 3.32$ & $81.53 \pm 0.89$ & $86.80 \pm 5.15$ & $82.69 \pm 1.26$ & $88.00 \pm 2.62$ & $82.45 \pm 0.82$ \\
\hline BOD & $135.33 \pm 5.69$ & $34.67 \pm 2.08$ & $74.31 \pm 2.66$ & $32.33 \pm 1.53$ & $76.11 \pm 0.48$ & $36.00 \pm 3.00$ & $73.32 \pm 3.18$ \\
\hline COD & $\begin{array}{c}1510.67 \pm \\
8.74\end{array}$ & $\begin{array}{c}399.67 \pm \\
12.50\end{array}$ & $73.55 \pm 0.73$ & $368.67 \pm 2.52$ & $75.60 \pm 0.11$ & $\begin{array}{c}383.00 \pm \\
8.00\end{array}$ & $74.64 \pm 0.51$ \\
\hline $\mathbf{T N}$ & $18.65 \pm 0.71$ & $3.58 \pm 0.08$ & $80.78 \pm 1.11$ & $2.98 \pm 0.13$ & $84.00 \pm 0.55$ & $3.17 \pm 0.23$ & $83.01 \pm 1.29$ \\
\hline $\mathbf{N H}_{3}$ & $7.97 \pm 0.86$ & $1.87 \pm 0.15$ & $76.59 \pm 1.35$ & $1.63 \pm 0.21$ & $79.46 \pm 3.08$ & $1.27 \pm 0.15$ & $84.07 \pm 2.33$ \\
\hline $\mathrm{NO}_{3}$ & $3.20 \pm 0.36$ & $0.43 \pm 0.15$ & $86.02 \pm 6.55$ & $0.53 \pm 0.15$ & $83.52 \pm 3.08$ & $0.00 \pm 0.00$ & $100.00 \pm 0.00$ \\
\hline $\mathbf{P}$ & $5.10 \pm 0.26$ & $1.00 \pm 0.10$ & $80.41 \pm 1.38$ & $1.07 \pm 0.12$ & $79.02 \pm 2.78$ & $1.20 \pm 0.20$ & $76.53 \pm 3.09$ \\
\hline
\end{tabular}

Data are average of three replicates; each value represents the mean \pm SD. 


\section{Fatty acid profiles}

After extraction of total lipids from the dried cells of each microalgal culture and alkaline transesterification to the extracted oils the produced fatty acid methyl esters were analyzed using Gas chromatography- mass spectroscopy (GCMS).Generally, nine fatty acids were detected in fatty acid profile of A. oryzae while with Chlorella fourteen fatty acids were detected. The presence of Myristic, Palmitic, Stearic, Oleic and Linoleic fatty acids in algal oil strongly supported their ability for good biodiesel production (Jitha and Madhu, 2016).

Referring to the results of total identified fatty acids, their percentage indicated that Anabaena and mixed culture cultivated in the poultry waste extract have the higher percentage of identified fatty acids $(99.1 \%)$. In the present study it is noted that microalgal fatty acids percentage contains a major proportion of saturated and polyunsaturated fatty acid methyl esters as shown in (Table 3). In addition the percentage of unsaturated fatty acids was higher than the percentage of saturated fatty acids in Anabaena (58.1 and $57.1 \%$ for control and waste samples), this increase is due to increase in content of polyunsaturated fatty acids mainly Linolinic fatty acid ranged between (26.9\% to 25.5\%), Hexadecadienoic fatty acid between 11.2 to $12.1 \%$ ). In contrary saturated fatty acids of Chlorella and mixed culture are more than unsaturated fatty acids, this increase is due to the presence of Myristic, Palmitic, Margaric and Stearic fatty acids in control and waste cultures with different percentages. The present result was previously recorded by Karemore et al.,(2013) who mentioned that alteration of environmental parameters, such as the composition of growth medium or the presence of special media components, affect on the nature, quantity, and composition of the desired fatty acids. Also Cuellar-Bermudez et al., (2015) reported that fatty acid profiles of cyanobacteria influenced under environmental stress conditions. 
Table 3: Fatty acids profiles of Anabaena, Chlorella and their mixed culture cultivated on $5 \mathrm{~g} / \mathrm{L}$ poultry waste extract for 14 days, data expressed as relative percentage.

\begin{tabular}{|c|c|c|c|c|c|c|}
\hline \multirow[b]{2}{*}{ Fatty acids } & \multicolumn{2}{|c|}{ Anabaena oryzae } & \multicolumn{2}{|c|}{ Chlorella vulgaris } & \multicolumn{2}{|c|}{ Mixture } \\
\hline & $\mathrm{BBM}$ & $\begin{array}{l}\text { Waste } \\
\text { extract } \\
(5 \mathrm{~g} / \mathrm{L})\end{array}$ & $\mathrm{BBM}$ & $\begin{array}{l}\text { Waste } \\
\text { extract } \\
(5 \mathrm{~g} / \mathrm{L})\end{array}$ & $\mathrm{BBM}$ & $\begin{array}{l}\text { Waste } \\
\text { extract } \\
(5 \mathrm{~g} / \mathrm{L})\end{array}$ \\
\hline Capric (C10:0) & nd & nd & 1.6 & 1.5 & 1.8 & 2.5 \\
\hline Lauric (C12:0) & nd & nd & 4.9 & 5.4 & 3.1 & 3.0 \\
\hline Myristic (C14:0) & 14.6 & 14.0 & 20.1 & 17.5 & 13.9 & 12.0 \\
\hline Palmitic (C16:0) & 16.7 & 17.3 & 17.02 & 14.9 & 16.5 & 16.3 \\
\hline Palmitoleic (C16:1) & 7.5 & 8.2 & 3.2 & 3.09 & 3.0 & 2.8 \\
\hline Hexadecadienoic C16:2 & 11.2 & 12.1 & nd & nd & 4.1 & 4.5 \\
\hline Margaric (C17:0) & nd & nd & 1.05 & 1.5 & 4.3 & 5.1 \\
\hline Stearic (C18:0) & 9.4 & 10.7 & 10.3 & 9.8 & 11.7 & 11.1 \\
\hline Oleic (C18:1) & 7.2 & 7.3 & 20.2 & 22.2 & 12.5 & 13.7 \\
\hline Linoleic (C18:2) & 5.3 & 4.0 & 11.1 & 12.0 & 7.7 & 8.2 \\
\hline Linolenic (C18:3) & 26.9 & 25.5 & 4.6 & 5.2 & 17.4 & 16.4 \\
\hline Arachidonic (C20:4) & Trace & nd & 0.87 & 0.9 & nd & 1.9 \\
\hline Behenic (C22:0) & nd & nd & 1.5 & 1.5 & 0.6 & 0.5 \\
\hline Lignoceric (C24:0) & nd & nd & 1.8 & 1.8 & 1.1 & 1.1 \\
\hline Others & 1.2 & 0.9 & 1.76 & 2.71 & 2.3 & 0.9 \\
\hline Total identified fatty acids $\%$ & 98.8 & 99.1 & 98.24 & 97.29 & 97.7 & 99.1 \\
\hline Saturated fatty acids $\%$ (SFA) & 40.7 & 42.0 & 58.25 & 53.9 & 53 & 51.6 \\
\hline $\begin{array}{c}\text { Monounsaturated Fatty acids\% } \\
\text { (MUFA) }\end{array}$ & 14.7 & 15.5 & 23.4 & 25.29 & 15.5 & 16.5 \\
\hline $\begin{array}{c}\text { Polyunsaturated Fatty acids\% } \\
\text { (PUFA) }\end{array}$ & 43.4 & 41.6 & 16.57 & 18.1 & 29.2 & 31 \\
\hline
\end{tabular}

Percentage of FAME was calculated based on peak area of individual peaks in the (GC-MS) spectrum. nd: not detected . 
The effect of different pretreatments methods ( lypholization, sonication, autoclave and microwave) on total lipid extracted using chloroform/methanol 2:1 $\mathrm{v} / \mathrm{v}$ as solvent system for five hours (Fig.2) showed that the lipid extracted from microalgal cells showed significant difference between four pretreatment methods and control. Pretreatments by microwave method showed the highest lipid yield (132.97, 271.34 and $208.93 \mathrm{mg}$ ) for Anabaena, Chlorella and mixed culture respectively with the highest percentage increase than control $(30.38$, 53.99 and $35.43 \%$ ).Sharma et al., (2016), deduced that microalgae cell membrane reduces the recovery of total lipid extraction because it acts as a barrier therefore, microwave pretreatment method causes cell disruption were applied before extraction in order to achieve high lipid efficiency. Moreover Cheng et al., (2013) reported that, microwaves accelerate the disruption of microalgae cells and enable easier lipid release. Microwave irradiation is also a faster and more efficient heating process, which directly contributes to molecular diffusion and mass transfer.

\section{Biodiesel production and characterization}

In mass production experiments, microalgal cells from Anabaena cultivated on poultry waste extract $(5 \mathrm{~g} / \mathrm{L})$ for 14 days were harvested, pretreated in microwave and then dried, oils were extracted, and converted to biodiesel (FAMEs) by transesterification as mentioned before.

Results in (Table 4) showed that $73.86 \%$ of total lipid of Anabaena transformed to biodiesel whereas the percentage of biodiesel production were 86.5 and $84.78 \%$ in C. vulgaris and mixed culture respectively. The $\mathrm{pH}$ of the produced biodiesel was between 7.1 for Anabaena and 8.1 for mixed culture, while it was 7.9 for Chlorella product. Sediments (glycerol, pigments,..ect.) recorded $26.14 \%, 13.55 \%$ and $15.22 \%$ of total lipids of Anabaena, Chlorella and mixed culture respectively; which is promising for other beneficial byproducts. After oil extraction microalgae cells residue can be used as rich source of carbohydrates and valuable byproducts. These results were compatible with previous researches, that the average of microalgae biodiesel production can be 10 to 20 times higher than that of other vegetable or seed oils (Rajak $\boldsymbol{e t}$ al., 2019). 


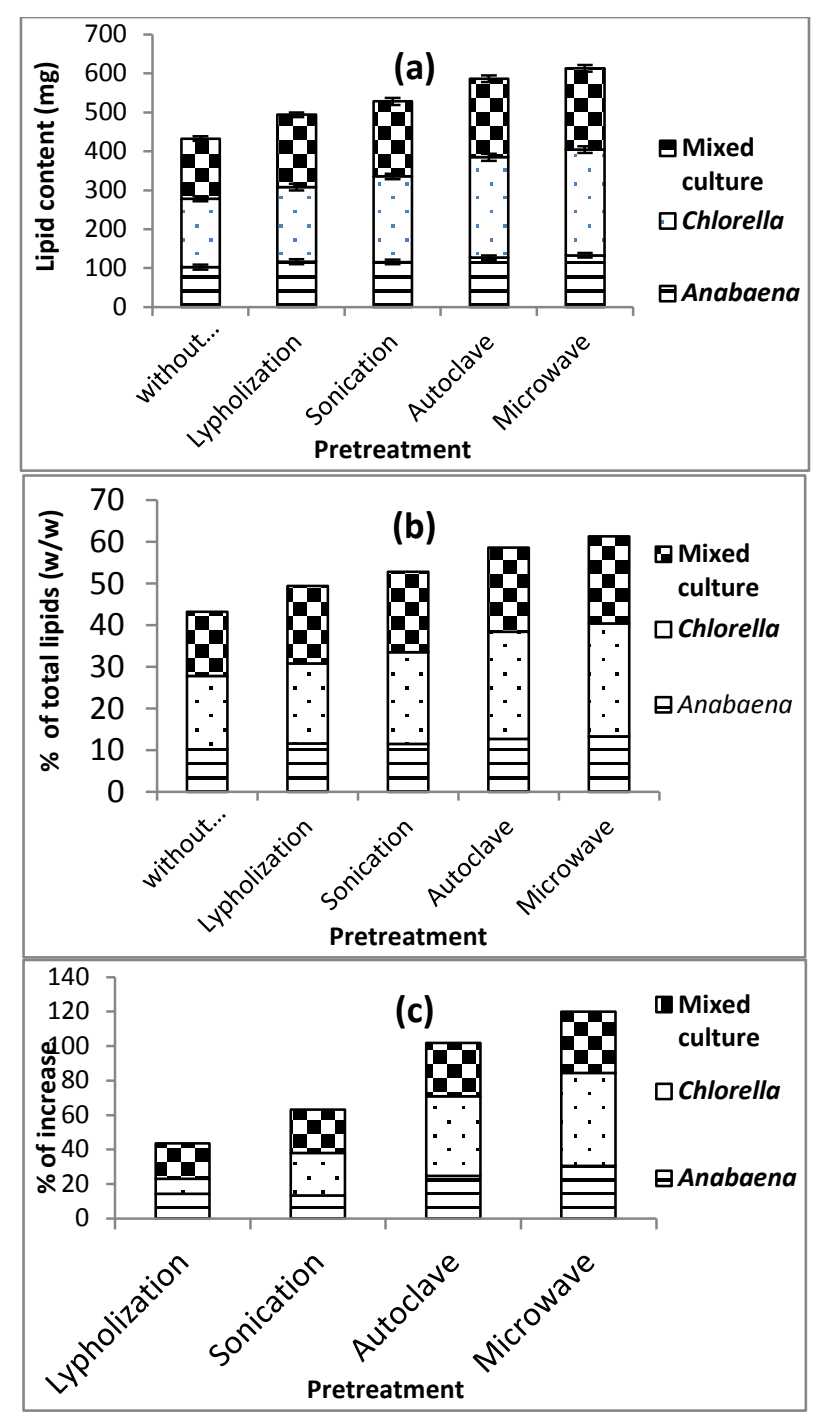

Fig. 2: Effect of some pretreatments on lipid content and percentage (w/w) of total lipids extracted from microalgal cells. (a) total lipids content (mg), (b) \% of total lipids, (c) \% of increase than control. 
Table 4: Percentage of biodiesel and sediments (Glycerol \& Pigments) in total lipid extracted from microalgal mass cultures grown on poultry waste extract $(5 \mathrm{~g} / \mathrm{L})$ for 14 days.

\begin{tabular}{|c|c|c|c|c|}
\hline Microalgae & $\begin{array}{c}\text { Total } \\
\text { lipids \% }\end{array}$ & $\begin{array}{c}\text { Biodiesel } \\
\%\end{array}$ & $\begin{array}{c}\text { Sediments } \\
\%\end{array}$ & pH \\
\hline Anabaena oryzae & $17.6 \pm 1.3$ & $13.0 \pm 0.8$ & $4.6 \pm 0.8$ & $7.1 \pm 0.35$ \\
\hline Chlorella vulgaris & $31.0 \pm 1.9$ & $26.8 \pm 1.1$ & $4.2 \pm 1.1$ & $7.9 \pm 0.4$ \\
\hline $\begin{array}{c}\text { Mixed culture } \\
(\text { A.Oryzae \& C.vulgaris })\end{array}$ & $23.0 \pm 1.3$ & $19.5 \pm 1.0$ & $3.5 \pm 1.0$ & $8.1 \pm 0.43$ \\
\hline
\end{tabular}

After separation of sediments (glycerol, pigments, ect.) and purification of the produced biodiesel, samples were analyzed. Recently the great response towards algal biodiesel production has been well-recognized as a sustainable alternative to conventional fuels. Nutrient supplementation with organic carbon sources resulted in incresed biomass, lipid content and lipid productivity (Abinandan et al., 2019). Comparison with biodiesel standards particularly American Society for Testing and Materials (ASTM), European Standards( EN) and the Egyptian Petrodiesel Standards (EPS), was necessary when reviewing biodiesel properties ( Table 5). Generally the properties of the produced biodiesel meet the ASTM, EN and EPS standards. The lower the iodine value the higher the cetane number and the better is the biodiesel. The (IV) was 88.4,63.5 and 80.2 which satisfies the (EN) standard. Cetane number was (54.4, 56.4 and 53.7 ) which was higher than the lower values that recommended by ASTM and EN standards and near that recommended by EPS standard in all samples that means a good ignition quality. The cold filter plugging point (CFPP) was (5.8) in Anabaena biodiesel which meet with the EN standards, so biodiesel can be used in cold weather. The oxidation stability is a significant fuel parameter it was higher than that required by ASTM and EN in all sample indicating good and stable biodiesel, The properties of microalgae biodiesel are very near to that of 
diesel, and any percentage of volume can be used without any modification in operating test engine (Rajak et al., 2019).

Table 5: Physico-chemical properties of the produced biodiesel of A.oryzae, C.vulgaris and their mixture grown on poultry waste extract (5g/L for 14 days), compared to international standards.

\begin{tabular}{|c|c|c|c|c|c|c|}
\hline \multirow{2}{*}{ parameters } & \multirow{2}{*}{$\begin{array}{c}\text { A. oryzae } \\
\text { product }\end{array}$} & \multirow{2}{*}{$\begin{array}{c}\text { C. vulgaris } \\
\text { product }\end{array}$} & \multirow{2}{*}{$\begin{array}{c}\text { A.oryzae }+ \\
\text { C. vulgaris } \\
\text { product }\end{array}$} & \multicolumn{3}{|c|}{ Biodiesel Standards } \\
\hline & & & & $\begin{array}{l}\text { ASTM } \\
\text { D6751 }\end{array}$ & $\begin{array}{c}\text { EN } \\
14214\end{array}$ & EPS \\
\hline Degree of unsaturation $(\mathrm{Du})$ & 98.7 & 61.5 & 78.5 & & & \\
\hline Saponification value $\mathrm{mg} / \mathrm{g}(\mathrm{SV})$ & 201.5 & 200.0 & 201.82 & & & \\
\hline Iodine value $\mathrm{g} \mathrm{I} / 100 \mathrm{~g}(\mathrm{IV})$ & 88.4 & 63.5 & 80.2 & & $\leq 120$ & \\
\hline Cetane number(CN) & 54.4 & 56.4 & 53.7 & $>47$ & $\geq 51$ & $>55$ \\
\hline $\begin{array}{l}\text { Long chain saturation factor } \\
\text { (LCSF) }\end{array}$ & 7.1 & 9.9 & 9.4 & & & \\
\hline Cold filter plugging point(CFPP) & 5.8 & 14.9 & 13.0 & -5 to -13 & $5-20$ & \\
\hline Pour point ${ }^{\circ} \mathrm{C}(\mathrm{PP})$ & 2.5 & 3.8 & 3.1 & -15 to 10 & & 4.5 \\
\hline Oxidation stability/h (OS) & 6.6 & 8.7 & 6.9 & 3 & $\geq 6$ & \\
\hline Higher heating value (HHV) & 36.14 & 41.74 & 39.22 & $>35$ & $>32.9$ & $>44.3$ \\
\hline Kinematic viscosity $\mathrm{mm}^{2} / \mathrm{s}$ & 3.52 & 4.07 & 3.81 & $1.9-6$ & $3.5-5$ & $1.6-7$ \\
\hline$P$, Density $\mathrm{g} / \mathrm{cm} 3$ & 0.793 & 0.893 & 0.858 & 0.878 & $0.86-0.9$ & $0.82-0.87$ \\
\hline Flash point ${ }^{\circ} \mathrm{C}$ & 112 & 131 & 120 & $>130$ & $>101$ & $>82$ \\
\hline Ash content, wt. $\%$ & Nil & Nil & Trace & & & $<0.01$ \\
\hline Total Sulphur, wt.\% & 0.01 & trace & trace & & & $<1$ \\
\hline Carbon residue & 0.03 & 0.04 & 0.04 & $<0.05$ & $<0.03$ & $<0.1$ \\
\hline
\end{tabular}




\section{Conclusion}

Cultivation of microalgae in poultry wastes extract as a promising alternative growth medium achieved a double goal. Algal biomass, lipid content and lipid productivity were enhanced than control, and this lipid could be transferred to ecofriendly biodiesel. The produced biodiesel has a properties compatible with the world standards and the role of algae in bioremediation of poultry waste was significant. So not only biodiesel production cost was reduced but also pollution and eutrophication of the ecosystem was decreased, which is a good promise for future applications for large scale production.

\section{References}

Abinandan, S., Subashchandrabose, S. R., Cole, N., Dharmarajan, R., Venkateswarlu, K. and Megharaj, M. (2019). Sustainable production of biomass and biodiesel by acclimation of non- acidophilic microalgae to acidic conditions. Bioresour. Technol. 271, 316-324 .

Abomohra, A., Wagner, M., El-Sheekh, M. and Hanelt, D. (2013). Lipid and total fatty acid productivity in photoautotrophic fresh water microalgae, Screening studies towards biodiesel production. Journal of Applied Phycology. 25 (4), 931-936.

Afify, A., Shalaby E.A. and Shanab, S. (2010). Enhancement of biodiesel production from different species of algae. Grasas Y Aceites. 61(4),416422.

Agwa, O.K. , Ibe, S.N. and Abu, G.O. (2012). Economically effective potential of Chlorella sp. for biomass and lipid production. J. Microbiol. Biotechnol. Res. 2(1), 35-45.

Agwa, O. K. and Abu, G. O. (2014). Utilization of poultry waste for the cultivation of Chlorella sp . for biomass and lipid production Int. J. Curr. Microbiol. App. Sci. 3(8), 1036-1047. 
Alam, F., Date, A., Rasjidin, R., Mobin, S., Moria, H. and Baqui, A. (2012). Biofuel from algae - is it a viable alternative? Procedia Eng. 49,221-227.

Ali, M., Sultana, R., Tahir, S., Watson, I. A. and Saleem, M. (2017). Prospects of microalgal biodiesel production in Pakistan - A review. Renewable and Sustainable Energy Reviews 80 , 1588-1596.

APHA (1998). Standard methods for the examination of water and wastewater, 20 ed., American Public Health Association Washington, DC.

APHA (2005). Standard methods for the examination of water and waste water 21 st ed. American public health association, 800 I street, NW, Washington, DC 20001-3710.

Bacenetti, J., Lovarelli, D., Ingrao C., Tricase, C., Negri, M. and Fiala, M. (2015). Assessment of the influence of energy density and feedstock transport distance on the environmental performance of methane from maize silages. Bioresour. Technol. 193, 256-265.

Bhatnagar, A., Bhatnagar, M., Chinnasamy, S. and Das, K.C. (2010). Chlorella minutisssima - promising fuel alga for cultivation in municipal wastewaters. Appl. Biochem. Biotech. 161, 523-536.

Bhatnagar, A., Chinnasamy, S., Singh, M. and Das, K. C. (2011). Renewable biomass production by mixotrophic algae in the presence of various carbon sources and wastewaters. Applied Energy. 88 (10), 3425-3431.

Cheng, J., Sun, J., Huang, Y., Feng, J., Zhou, J. and Cen, K. (2013). Dynamic microstructures and fractal characterization of cell wall disruption for microwave irradiation- assisted lipid extraction from wet microalgae. Bioresour. Technol. 150, 67-72.

Cho, S., Lee, N., Park, S., Yu, J, Luong, T.T., Oh, Y.K. and Lee, T. (2013). Microalgae cultivation for bioenergy production using wastewaters from a municipal WWTP as nutritional sources. Biores Technol 131, 515-520.

Converti, A., Casazza, A.A., Ortiz, E.Y., Perego, P. and Del Borghi, M. (2009). Effect of temperature and nitrogen concentration on the growth and lipid content of Nannochloropsis oculata and Chlorella vulgaris for biodiesel production. Chem. Eng. Process. 48 (6), 1146-1151. 
Cuellar-Bermudez, S.P., Romero-Ogawa, M.A., Vannela, R., Lai, Y.S. Rittmann, B.E. and Parra-Saldivar, R. (2015). Effects of light intensity and carbon dioxide on lipids and fatty acids produced by Synechocystis sp. PCC6803 during continuous flow. Algal Res.12 ,10-16.

Dytham, C. ,1999. Choosing and using statistics, a biologist's guide. Blackwell science, Ltd., London, United Kingdom.

Eladel, H.,Abomohra,A. F.,Battah, M., Mohmmed, S.and Radwan, A. (2019). Evaluation of Chlorella sorokiniana isolated from local municipal wastewater for dual application in nutrient removal and biodiesel production. Bioprocess and Biosystems Engineering. 42 (3), 425- 433. https,//doi.org/10.1007/s00449-018-2046-5.

Gupta,V.K. and Tuohy, M.G. (2013). Biofuel technologies, recent developments. Berlin Heidelberg, Springer.

Jacob-Lopes, E., Lacerda, L. and Franco, T.T. (2008). Biomass production and carbondioxide fixation by Aphanothece microscopica Nageli in a bubble column photobioreactor. Biochem Engin J. 40(1),27 34.

Jacob-Lopes, E., Scoparo,C., Lacerda, L. and Franco, T.T. (2009). Effect of light cycles(night/day) on $\mathrm{CO} 2$ fixation and biomass production by microalgaein photobioreactors Chemical Engineering and Processing. 48(1),306 -310.

Jitha ,G. and Madhu G. (2016). Cultivation of Oscillatoria SP in Dairy Waste Water in Two Stage Photo Bioreactors for Biodiesel Production. Civil Engineering and Urban Planning, An International Journal (CiVEJ) 3 (2),87 - 96.

Jones, C.S. and Mayfield, S.P. (2012). Algae biofuels, versatility for the future of bioenergy. Curr. Opin. Biotechnol. 23(3), 346-51.

Karemore, A., Pal, R. and Sen, R. (2013). Strategic enhancement of algal biomass and lipid in Chlorococcum infusionum as bioenergy feedstock. Algal Res. 2 (2), 113-121.

Kligerman, D.C. and Bouwer, E. J. (2015). Prospects for biodiesel production from algae-based wastewater treatment in Brazil, A review. Renewable and Sustainable Energy Reviews. 52, 1834-1846. 
Kothari, R.,Pathak, V.V.,Kumar, V. and Singh D.P. (2012). Experimental study for growth potential of unicellular alga Chlorella pyrenoidosa on dairy waste water, an integrated approach for treatment an biofuel production. Bioresour. Technol. 116, 466-470.

Lang, X. Dalai, A.K. Bakhshi, N.N. Reaney, N. and Hertz, P.B. (2002). Preparation and characterization of biodiesels from various Bio-Oils. Bioresour. Technol. 80, 53-62.

Lee, J.Y. , Yoo, C., Jun, S.Y., ,Ahn, C.Y. and Oh, H.M. (2010). Comparison of several methods for effective lipid extraction from microalgae. Bioresour. Technol. 101, S75-S77.

Lee, A.F. and Wilson, K. (2015). Recent developments in heterogeneous catalysis for the sustainable production of biodiesel. Catal. Today $242,3-$ 18.

Manzoor, M., Tabassum, F., Javaid, H. and JI, Q. (2015). Lucrative future of microalgal biofuels in Pakistan, a review. Int. J. Energy Environ Eng. 6,393- 403.

Markou, G.,Iconomou, D.,Sotiroudis, T., Israilides, C. and Muylaert, K. (2015). Exploration of using stripped ammonia and ash from poultry litter for the cultivation of the cyanobacterium Arthrospira platensis and the green microalga Chlorella vulgaris. Bioresour. Technol. 196 , 459-468.

Moreki, J. C. and Keaikitse, T., (2013). Poultry waste management practices in selected poultry operations around Gaborone, Botswana. Int. J. Curr. Microbiol. App. Sci. 2 (7), 240-248.

Nadiah, W.,Kadir, A.,Kee, M.,Uemura, Y.,Wei, J. and Teong, K. (2018). Harvesting and pre-treatment of microalgae cultivated in wastewater for biodiesel production, A review. Energy Conversion and Management 171, 1416-1429.

Posten, C. and Schaub, G. (2009). Microalgae and terrestrial biomass as source for fuels - A process view. J. Biotechnol. 142, 64-69.

Rajak, U.,Nashine, P. and Verma, T. N. (2019). Assessment of diesel engine performance using Spirulina microalgae biodiesel. Energy 166, 10251036. 
Rawat, I., Ranjith Kumar, R., Mutanda, T. and Bux, F. (2011). Dual role of microalgae, phycoremediation of domestic wastewater and biomass production for sustainable biofuels production. Appl. Energy 88, 341124.

Sadasivam, S. and Manickam, A. (1996). Biochemical methods, 2nd Edition.

Sharma, A., Sahoo, P. K., Singhal, S. and Joshi, G. (2016). Exploration of upstream and downstream process for microwave assisted sustainable biodiesel production from microalgae Chlorella vulgaris. Bioresour. Technol. 216, 793-800.

Sivaramakrishnan, R. and Incharoensakdi, A. (2017). Enhancement of total lipid yield by nitrogen, carbon, and iron supplementation in isolated microalgae. J. Phycol. 53, 855-868.

Spolaore, P., Joannis-Cassan, C., Duran, E. and Isambert, A. (2006). Commercial applications of microalgae. J. of Bioscience and Bioengin.101 (2), 87-96. 


\title{
إنتاج الديزل الحيوي وإزالة المغذيات بواسطة الطحالب الدقيقة المستزرعة على فضلاث الدواجن
}

\author{
عفت فهي شبانة ، فاطمة الزهراء توفيق ذكي، هناء سيد شلبي \\ قسم النبات والمبكروبولوجي، كلبة العلوم، جامعة القاهرة، مصر
}

تعتبر الطحالب الاقيقة مادة خام أساسية لكثيرمن المنتجات المتجددة وكذلك في التطبيقات المختلفة

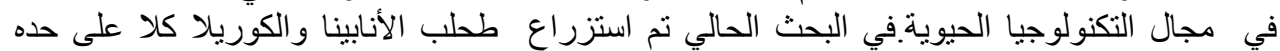

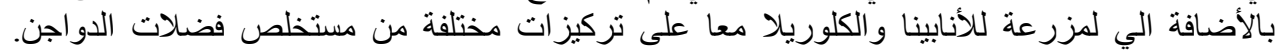

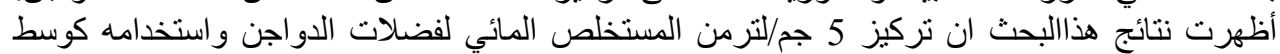

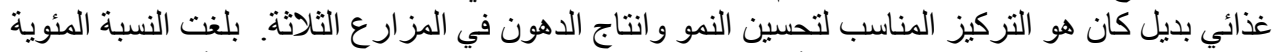

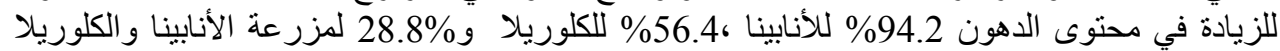

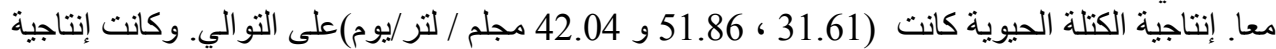

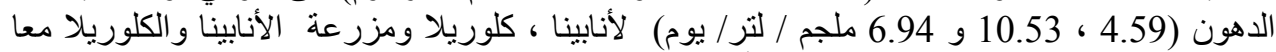

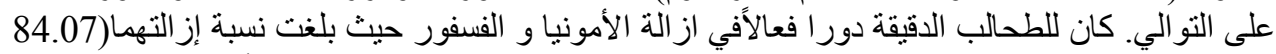

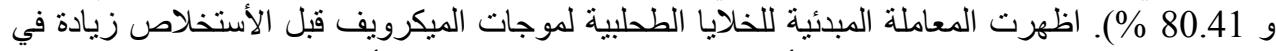

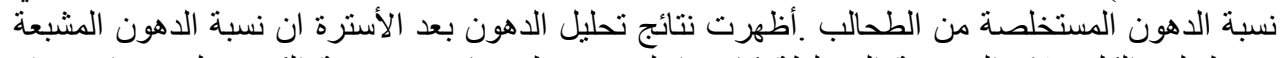

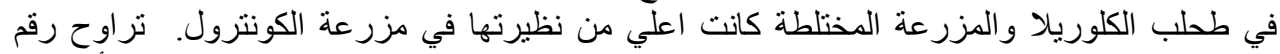

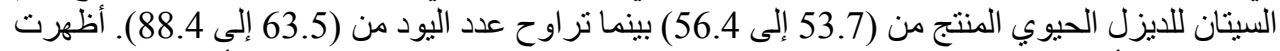

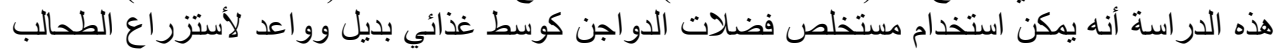

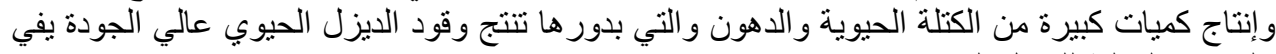
بالمعايير الدولية للديزل الحيوي. 